39 De Palma GD, Galloro G, Sicialiano S, et al Unilateral versus bilateral endoscopic hepatic duct drainage in patients with malignant hilar biliary obstruction: results of a prospective, randomized, and controlled study. Gastrointest Endosc 2001:53:547-53.

40 Heina $M$, Pruckmayer $M$, Raderer $M$. The role of chemotherapy and radiation in the management of biliary cancer: a review of the literature. Eur $J$ Cancer 1998:34:977-86.

41 Anderson CD, Pinson CW, Berlin J, et al. Diagnosis and treatment of cholangiocarcinoma. Oncologist 2004:9:43-57.

42 Tsavaris N, Kosmas C, Gouveris P, et al. Weekly gemcitabine for the treatment of biliary tract and gallbladder cancer. Invest New Drugs 2004;22:193-8.

43 Burris HA 3rd, Moore MJ, Andersen J, et al Improvements in survival and clinical benefit with gemcitabine as first line therapy for patients with advanced pancreatic cancer. J Clin Oncol 1997:15:2403-13.

44 Glimelius B, Hoffman K, Sjoden PO, et al Chemotherapy improves survival and quality of life in advanced biliary and pancreatic cancer. Ann Oncol 1996:7:593-600.

45 Ducreux M, Rougier P, Fandi A, et al. Effective treatment of advanced bilary tract carcinoma using 5-FU continuous infusion with cisplatin. Ann Oncol 1998;9:653-56
46 Bowling TE, Galbraith SM, Hatfield AR, et al. A retrospective comparison of endoscopic stenting alone with stenting and radiotherapy in nonresectable cholangiocarcinoma. Gut 1996;39:852-5.

47 Foo ML, Gunderson LL, Bender CE, et al. External radiation therapy and transcatheter iridium in the treatment of extrahepatic bile duct carcinoma. Int J Radiat Oncol Biol Phys 1997:39:929-35.

48 Pitt HA, Nakeeb A, Abrams RA, et al. Peri-hilar cholangiocarcinoma: Post-operative radiation therapy does not improve survival. Ann Surg 1995;221: 788-98

\section{Chronic diarrhoea}

\section{R Spiller}

$\mathrm{T}$ his is an introduction to the Gut tutorial "Chronic diarrhoea" hosted on BMJ Learning-the best available learning website for medical professionals from the BMJ Group.

Diarrhoea predominant irritable bowel syndrome is by far the most common cause of abdominal pain and diarrhoea in patients aged 20 to 40 years. Irritable bowel syndrome as a whole affects around $10 \%$ of the UK population. The female to male ratio is 1.5:1. Between 6 and $17 \%$ of patients with irritable bowel syndrome report that their symptoms began after an attack of acute bacterial gastroenteritis. Indeed, bacterial gastroenteritis in the previous year proved to be the strongest predictor of the development of irritable bowel syndrome. Around 3\% of patients meeting the Rome criteria for irritable bowel syndrome have been shown to suffer from unrecognised coeliac disease. Although initially asymptomatic, many patients, when put on a gluten free diet, recognise that they have been tolerating low grade symptoms for many years. The yield from further investigations is small but occasionally of value. In patients with an established diagnosis of irritable bowel syndrome, $2 \%$ of stool samples were abnormal and around $2 \%$ of colonoscopies show occult or microscopic inflammatory bowel disease. Lactose intolerance is commonly diagnosed, but may be unhelpful in management in the UK because many patients with lactose intolerance have learnt to avoid foods that contain lactose. Unlike irritable bowel syndrome, Crohn's disease is marked by characteristic weight loss, abdominal tenderness or mass with perianal soreness and discolouration. Anaemia and raised inflammatory markers, such as $\mathrm{C}$ reactive protein and erythrocyte sedimentation, are tests that discriminate irritable bowel syndrome from patients with other illnesses.

To access the tutorial (Interactive Case History), click on BMJ Learning: Take this module on BMJ Learning from the content box at the top right and bottom left of the online article. For more information please go to: http://gut.bmj. $\mathrm{com} /$ tutorials/collection.dtl

If prompted, subscribers must sign into Gut with their journal's username and password. All users must also complete a one-time registration on BMJ Learning and subsequently log in (with a BMJ Learning username and password) on every visit.

Gut 2007:56:1756-1757.

doi: 10.1136/gut.2007.138867

Correspondence to: Robin Spiller, Professor of Gastroenterology, Division of Gastroenterology, University Hospital Nottingham, Nottingham NG7 2UH, UK; robin.spiller@nottingham.ac.uk Competing interests: None.

\section{REFERENCES}

1 Taylor TV, Lambert ME, Qureshi S, et al. Should cholecystectomy be combined with vagotomy and pyloroplasty? Lancet 1978;1:295-8.

2 Taylor TV, Lambert ME, Torrance HB. Value of bileacid binding agents in post-vagotomy diarrhoea. Lancet 1978;1:635-6.

3 Al Hadrani A, Lavelle-Jones $M$, Kennedy $N$, et al. Bile acid malabsorption in patients with postvagotomy diarrhoea. Ann Chir Gynaecol 1992:81:351-3.

4 Sauter GH, Moussavian AC, Meyer G, et al. Bowe habits and bile acid malabsorption in the months after cholecystectomy. Am J Gastroenterol 2002;97:1732-5.

5 Fort JM, Azpiroz F, Casellas F, et al. Bowel habit after cholecystectomy: physiological changes and clinical implications. Gastroenterology 1996;111:617-22.

6 Szajewska H, Kantecki M, Albrecht $P$, et al. Carbohydrate intolerance after acute gastroenteritis - a disappearing problem in Polish children. Acta Paediatr 1997:86:347-50.

7 Parry SD, Barton JR, Welfare MR. Is lactose intolerance implicated in the development of postinfectious irritable bowel syndrome or functional diarrhoea in previously asymptomatic people? Eur J Gastroenterol Hepatol 2002;14:1225-30.

8 Ladas S, Papanikos J, Arapakis G. Lactose malabsorption in Greek adults: correlation of small bowel transit time with the severity of lactose intolerance. Gut 1982;23:968-73.

9 Parker TJ, Woolner JT, Prevost AT, et al. Irritable bowel syndrome: is the search for lactose intolerance justified? Eur J Gastroenterol Hepatol 2001;13:219-25.

10 Suarez FL, Savaiano DA, Levitt MD. A comparison of symptoms after the consumption of milk or lactose-hydrolyzed milk by people with selfreported severe lactose intolerance. N Engl J Med 1995;333:1-4.

11 Bohmer CM, Tuynman HE. The clinical relevance of lactose malabsorption in irritable bowel syndrome. Eur J Gastroenterol Hepatol 1996;8:1013-16.

12 Swallow DM. Genetics of lactase persistence and lactose intolerance. Annu Rev Genet 2003:37:197-219.

13 Sanders SW, Tolman KG, Reitberg DP. Effect of a single dose of lactase on symptoms and expired hydrogen after lactose challenge in lactoseintolerant subjects. Clin Pharm 1992;11:533-8.

14 Jones J, Boorman J, Cann P, Forbes A, et al. British Society of Gastroenterology guidelines for the management of the irritable bowel syndrome. Gut 2000;47(Suppl 2), 1-19.

15 Heaton KW, Radvan J, Cripps H, et al. Defecation frequency and timing, and stool form in the general population: a prospective study. Gut 1992:33:818-24.

16 Everhart JE, Go VL, Johannes RS, et al. A longitudinal survey of self-reported bowel habits in the United States. Dig Dis Sci 1989;34:1 153-62.

17 Hungin AP, Whorwell PJ, Tack J, et al. The prevalence, patterns and impact of irritable bowel syndrome: an international survey of 40,000 subjects. Aliment Pharmacol Ther 2003; 17:643-50.

18 Longstreth GF, Hawkey CJ, Mayer EA, et al. Characteristics of patients with irritable bowel syndrome recruited from three sources: implications for clinical trials. Aliment Pharmacol Ther 2001;15:959-64.

19 Gwee KA, Graham JC, McKendrick MW, et al. Psychometric scores and persistence of irritable bowel after infectious diarrhoea. Lancet 1996:347:150-3.

20 Gwee KA, Leong YL, Graham C, et al. The role of psychological and biological factors in postinfective gut dysfunction. Gut 1999:44:400-6.

21 Neal KR, Hebden J, Spiller R. Prevalence of gastrointestinal symptoms six months after bacterial gastroenteritis and risk factors for development of the irritable bowel syndrome: postal survey of patients. BMJ 1997;314:779-82.

22 Spiller RC. Postinfectious irritable bowel syndrome. Gastroenterology 2003;124:1662-71

23 Rodriguez LA, Ruigomez A. Increased risk of irritable bowel syndrome after bacterial gastroenteritis: cohort study. BMJ 1999;318:565-6.

24 Cann PA, Read NW, Holdsworth CD, et al. Role of loperamide and placebo in management of irritable bowel syndrome (IBS). Dig Dis Sci 1984;29:239-47. 
25 Vanner SJ, Depew WT, Paterson WG, et al. Predictive value of the Rome criteria for diagnosing the irritable bowel syndrome. Am J Gastroenterol 1999;94:2912-7.

26 Thompson WG, Longstreth GF, Drossman DA, et al. Functional bowel disorders and functional abdominal pain. Gut, 1999;45(Suppl 2), 43-7.

27 Lee FI, Costello FT. Crohn's disease in Blackpool incidence and prevalence 1968-80. Gut 1985;26:274-8.

28 Sanders DS, Hurlstone DP, Stokes RO, et al. Changing face of adult coeliac disease: experience of a single university hospital in South Yorkshire. Postgrad Med J 2002;78:31-3.

29 Sanders DS, Carter MJ, Hurlstone DP, et al. Association of adult coeliac disease with irritable bowel syndrome: a case-control study in patients fulfilling ROME II criteria referred to secondary care. Lancet 2001;358:1504-8.

30 Ciclitira PJ, King AL, Fraser JS. AGA technical review on Celiac Sprue. American Gastroenterological Association. Gastroenterology 2001;120:1526-40.

31 Chester AC, MacMurray FG, Restifo MD, et al. Giardiasis as a chronic disease. Dig Dis Sci 1985:30:215-18.

32 Bendig DW. Diagnosis of giardiasis in infants and children by endoscopic brush cytology. J Pediatr Gastroenterol Nutr 1989:8:204-6.

33 Farthing MJ. Giardiasis. Gastroenterol Clin North Am 1996;25:413-515.

34 Vesy CJ, Peterson WL. Review article: the management of Giardiasis. Aliment Pharmacol Ther 1999; 13:843-50.

35 Loftus EV. Microscopic colitis: epidemiology and treatment. Am J Gastroenterol 2003;98:S31-6.

36 Olesen M, Eriksson S, Bohr J, et al. Lymphocytic colitis: a retrospective clinical study of 199 Swedish patients. Gut 2004;53:536-41.

37 Olesen M, Eriksson S, Bohr J, et al. Microscopic colitis: a common diarrhoeal disease. An epidemiological study in Orebro, Sweden, 19931998. Gut 2004;53:346-50.

38 Fernandez-Banares $F$, Esteve $M$, Salas $A$, et al. Bile acid malabsorption in microscopic colitis and in previously unexplained functional chronic diarrhea. Dig Dis Sci 2001:46:2231-8.

39 Bolin TD, Davis AE, Duncombe VM. A prospective study of persistent diarrhoea. Aust N Z J Med 1982;12:22-6
40 Zigmond AS, Snaith RP. The hospital anxiety and depression scale. Acta Psychiatr Scand 1983:67:361-70.

41 Kruis W, Thieme C, Weinzierl M, et al. A diagnostic score for the irritable bowel syndrome. Its value in the exclusion of organic disease. Gastroenterology 1984;87:1-7.

42 Creed F. The relationship between psychosocial parameters and outcome in irritable bowel syndrome. Am J Med 1999; 107:74S-80S

43 Whitehead WE, Bosmaiian $\mathrm{L}$, Zonderman $\mathrm{AB}$, et al Symptoms of psychologic distress associated with irritable bowel syndrome. Comparison of community and medical clinic samples. Gastroenterology 1988;95:709-14.

44 Smith RC, Greenbaum DS, Vancouver JB, et al. Psychosocial factors are associated with health care seeking rather than diagnosis in irritable bowel syndrome. Gastroenterology 1990;98:293-301.

45 Hamm LR, Sorrells SC, Harding JP, et al. Additional investigations fail to alter the diagnosis of irritable bowel syndrome in subjects fulfilling the Rome criteria. Am J Gastroenterol 1999;94:1279-82.

46 Tolliver BA, Herrera JL, DiPalma JA. Evaluation of patients who meet clinical criteria for irritable bowe syndrome. Am J Gastroenterol 1994;89:176-8.

47 Jones JIW, Richardson P, Hebden JM, et al. Value of simple screening tests for the diagnosis of chronic diarrhoea. Gut 1999;44:A12.

48 Gilat T, BenHur H, Gelman-Malachi E, et al. Alterations of the colonic flora and their effect on the hydrogen breath test. Gut 1978;19:602-5.

49 Newcomer AD, McGill DB, Thomas PJ, et al. Tolerance to lactose among lactase-deficient American Indians. Gastroenterology 1978;74:44-6

50 Palmer KR, Corbett CL, Holdsworth CD. Doubleblind cross-over study comparing loperamide, codeine and diphenoxylate in the treatment of chronic diarrhea. Gastroenterology 1980;79:1272-5.

51 Cann PA, Read NW, Brown C, et al. Irritable bowe syndrome: relationship of disorders in the transit of a single solid meal to symptom patterns. Gut 1983;24:405-11

52 Lavo B, Stenstam M, Nielsen A-L. Loperamide in treatment of irritable bowel syndrome - A doubleblind placebo controlled study. Scand J Gastroenterol 1987;22:77-80.
53 Cremonini F, Delgado-Aros S, Camilleri M. Efficacy of alosetron in irritable bowel syndrome: a metaanalysis of randomized controlled trials. Neurogastroenterol Motil 2003;15:79-86.

54 Glaxo Wellcome withdraws irritable bowel syndrome medication. FDA Consum 2001;35:3

55 Camilleri M. Safety concerns about alosetron. Arch Intern Med 2002;162:100-1.

56 Friedel D, Thomas R, Fisher RS. Ischemic colitis during treatment with alosetron. Gastroenterology $2001 ; 120: 557-60$

57 Kamm MA. Review article: the complexity of drug development for irritable bowel syndrome. Aliment Pharmacol Ther 2002;16:343-51.

58 Wolfe SG, Chey WY, Washington MK, et al. Tolerability and safety of alosetron during long-term administration in female and male irritable bowel syndrome patients. Am J Gastroenterol 2001;96:803-11.

59 Williams AJK, Merrick MV, Eastwood MA. Idiopathic bile acid malabsorption - A review of clinical presentation, diagnosis, and response to treatment. Gut 1991;32:1004-6.

60 Sinha L, Liston R, Testa HJ et al Idiopathic bile acid malabsorption: qualitative and quantitative clinical features and response to cholestyramine. Aliment Pharmacol Ther 1998;12:839-44.

61 Clouse RE, Lustman PJ, Geisman RA, et al. Antidepressant therapy in 138 patients with irritable bowel syndrome: A five-year clinical experience. Aliment Pharmacol Ther 1994;8:409-16.

62 Rajagopalan M, Kurian G, John J. Symptom relief with amitriptyline in the irritable bowe syndrome. J Gastroenterol Hepatol 1998;13:738-41.

63 Greenbaum DS, Mayle JE, Vanegeren LE, et al Effects of desipramine on irritable bowel syndrome compared with atropine and placebo. Dig Dis $\mathrm{Sci}_{\mathrm{i}}$ 1987:32:257-66.

64 Jackson JL, O'Malley PG, Tomkins G, et al. Treatment of functional gastrointestinal disorders with antidepressant medications: a meta-analysis. Am J Med 2000;108:65-72

65 Drossman DA, Toner BB, Whitehead WE, et al. Cognitive-behavioral therapy versus education and desipramine versus placebo for moderate to severe functional bowel disorders. Gastroenterology 2003;125:19-31.

\section{Crohn's disease or abdominal tuberculosis?}

\section{A Forbes}

T his is an introduction to the Gut tutorial "Crohn's disease or abdominal tuberculosis?" hosted on BMJ Learning - the best available learning website for medical professionals from the BMJ Group.

A case-based discussion highlights recent trends in the investigation of patients suspected to have Crohn's disease and their management. The phenotype of Crohn's disease can be more accurately described using Vienna classification and formal assessment of disease activity can be performed using Crohn's Disease Activity Index or Harvey Bradshaw index, although their application in routine practice remains limited. Conventional tests, such as barium follow through, are still useful in the investigation of patients with symptoms and signs suggestive of small bowel disease, whereas non-invasive tests, such as ultrasound, may assist in decision making, such as indication and timing of surgery in Crohn's disease. Ileocaecectomy with removal of all macroscopic disease is followed by sustained remission for up to 10 years in roughly $30 \%$ of Crohn's disease patients who receive no further treatment. However, meta-analysis demonstrates a small but statistically significant benefit from the use of mesalazine in prolonging remission in patients in whom the remission has been obtained surgically. Limited data available suggest that azathioprine provides benefit in the post-operative Crohn's patient. Stopping smoking is effective in prolonging remission in Crohn's disease.

To access the tutorial (Interactive Case History), click on BMJ Learning: Take this module on BMJ Learning from the content box at the top right and bottom left of the online article. For more information please go to: http://gut.bmj. com/tutorials/collection.dtl

If prompted, subscribers must sign into Gut with their journal's username and password. All users must also complete a one-time registration on BMJ Learning and subsequently log in (with a BMJ Learning username and password) on every visit.

Gut 2007;56:1757-1758. doi: $10.1136 /$ gut.2007.138875

Correspondence to: A Forbes, St Mark's Hospita and Academic Institute, Watford Road, Harrow HA1 3UJ, UK; alastair.forbes@ic.ac.uk

Competing interests: None. 